University of Louisville

ThinkIR: The University of Louisville's Institutional Repository

Electronic Theses and Dissertations

$5-2019$

\title{
Treatment of electric utility wastewaters by sol-gel solidification and stabilization
}

Alex Kearns

University of Louisville

Follow this and additional works at: https://ir.library.louisville.edu/etd

Part of the Environmental Engineering Commons

\section{Recommended Citation}

Kearns, Alex, "Treatment of electric utility wastewaters by sol-gel solidification and stabilization" (2019). Electronic Theses and Dissertations. Paper 3451.

https://doi.org/10.18297/etd/3451

This Master's Thesis is brought to you for free and open access by ThinkIR: The University of Louisville's Institutional Repository. It has been accepted for inclusion in Electronic Theses and Dissertations by an authorized administrator of ThinkIR: The University of Louisville's Institutional Repository. This title appears here courtesy of the author, who has retained all other copyrights. For more information, please contact thinkir@louisville.edu. 


\title{
TREATMENT OF ELECTRIC UTILITY WASTEWATERS BY SOL-GEL SOLIDIFICATION AND STABILIZATION
}

\author{
By \\ Alex Kearns \\ B.S. Chemical Engineering, University of Louisville, 2018
}

\begin{abstract}
A Thesis
Submitted to the Faculty of the

University of Louisville
\end{abstract}

J. B. Speed School of Engineering

as Partial Fulfillment of the Requirements

for the Professional Degree

\section{MASTER OF ENGINEERING}

Department of Chemical Engineering

May 2019 
[page left intentionally blank] 
TREATMENT OF ELECTRIC UTILITY WASTEWATERS BY SOL-GEL SOLIDIFICATION AND STABILIZATION

Submitted by:

$$
\text { Alex Kearns }
$$

A Thesis Approved on

$$
\text { (Date) }
$$

by the Following Reading and Examination Committee:

Dr. Gautam Gupta, Thesis Director

Dr. Robert S. Keynton

Dr. Jim Gerstle

Dr. Mahyar Ghorbanian 


\section{ACKNOWLEDGEMENTS}

Foremost, I thank my parents for their unwavering support in all my endeavors. I also thank all my family and friends for their support over the years.

I thank my thesis director Dr. Gautam Gupta and LG\&E-KU advisor Dr. Mahyar Ghorbanian for their support and encouragement as I progressed through my research. The report as follows would not be possible without the countless hours they have poured into this project. I would also like to thank Dr. Meenakshi Bansal from Thomas More University for her assistance in the collection of ICP-AES and Raman spectroscopy data. I thank all members of my committee for their time and guidance.

I thank Louisville Gas \& Electric and Kentucky Utilities for their financial support in the project. Additionally, I thank the following technical teams at LG\&E and KU for assistance in collecting samples, interpretation of regulations, and much more: Technology Research and Analysis, Trimble County Operations, Gas Storage Operations, and Environmental Affairs.

I thank the Gupta Research Lab for their immense assistance in the procurement of supplies, demonstration of techniques, and support in my work. I thank Alex Gupta, Blake Martin, Charles Zhao, and Theodore Kalbfleisch for their individual contributions in teaching me about sol-gel processing and various characterization methods. 
I thank Dr. Thomas Starr and the Rapid Prototyping Center for their assistance in the production of complex parts. I thank the Conn Center for Renewable Energy and Chemistry Department at Thomas More for allowing me to use their equipment. 


\begin{abstract}
To meet the demands of new regulations on coal-fired power plants, many treatment scenarios require a zero-liquid discharge (ZLD) approach. Two revisions to regulations in 2015, the Effluent Limitations Guidelines (ELG) and Coal Combustion Residuals (CCRs) rule, drastically changed the treatment approach for managing effluents at coal-fired plants. In some scenarios, coal-fired plants retired early deeming the capital cost for maintaining compliance too expensive. Traditionally, stabilization/solidification (S/S) ZLD technologies have fallen in two categories: cementitious and vitrification. However, neither approach offers the ideal solution for coal-fired power plants needing ZLD by S/S methods. In what follows, a novel sol-gel encapsulation method with Silane precursors is evaluated as an alternative S/S effluent treatment. It will be shown that sol-gel encapsulation can be used to solidify various wastewater effluents from an LG\&E-KU power plant. The encapsulated solids successfully retained positively-charged contaminants during leaching analyses, while struggling to retain negatively-charged contaminants. Based on the results shown, it is proposed that the negatively-charged Silicon Dioxide network chemically fixates positively-charged contaminants, leading to the retention of those contaminants. These results demonstrate that sol-gel encapsulation can be developed as an alternative S/S technique to meet the challenges of ZLD regulations. It is anticipated that the work presented will be a starting point for further development of S/S treatment by sol-gel encapsulation.
\end{abstract}




\section{TABLE OF CONTENTS}

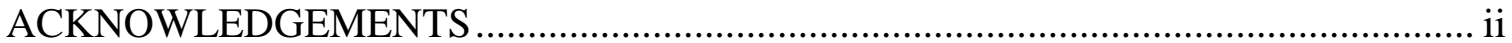

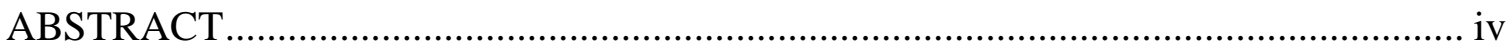

LIST OF ABBREVIATIONS AND SYMBOLS ...................................................... vi

LIST OF TABLES ........................................................................................ vii

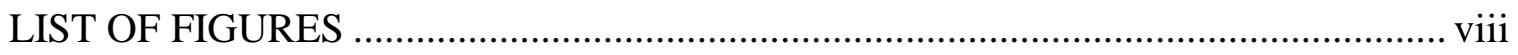

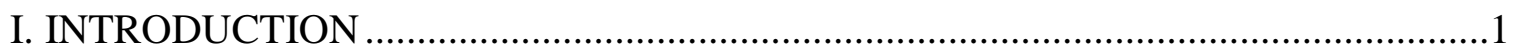

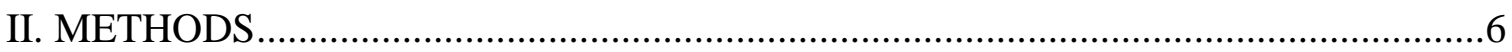

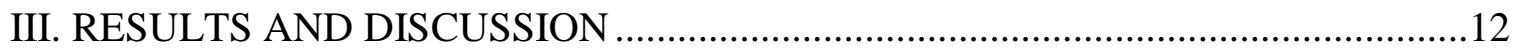

Process Characterization ................................................................................ 13

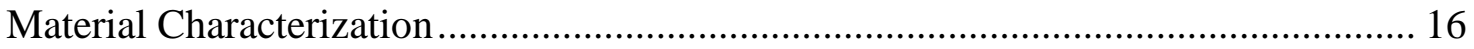

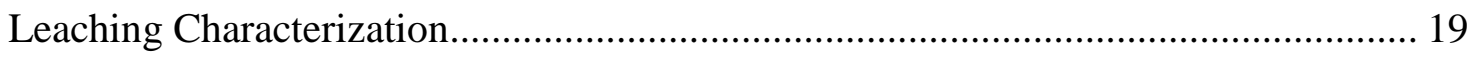

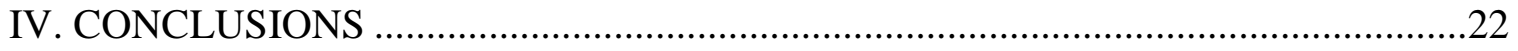

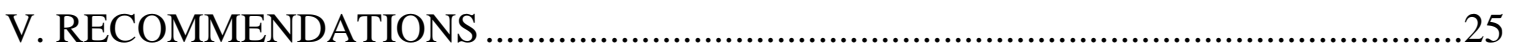

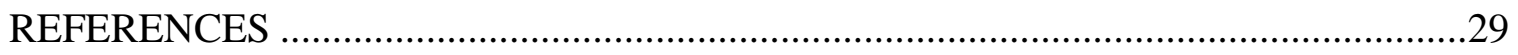

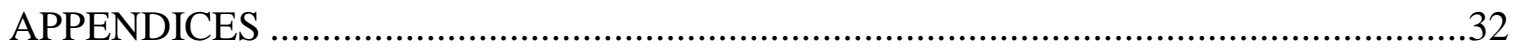

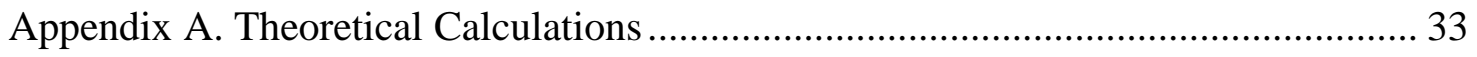

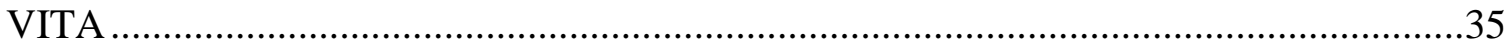




\section{LIST OF ABBREVIATIONS AND SYMBOLS}

$\begin{array}{ll}\text { BAP } & \text { Bottom Ash Pond } \\ \text { CBAP } & \text { Concentrated Bottom Ash Pond } \\ \text { CCRs } & \text { Coal Combustion Residuals } \\ \text { CFA } & \text { Coal Fly Ash } \\ \text { DOE } & \text { United States Department of Energy } \\ \text { EIS } & \text { Electrochemical Impedance Spectroscopy } \\ \text { ESP } & \text { Electrostatic Precipitator } \\ \text { FGD } & \text { Flue Gas Desulfurization } \\ \text { FGMC } & \text { Flue Gas Mercury Control } \\ \text { FT-IR } & \text { Fourier Transform-Infrared Spectroscopy } \\ \text { ICP-AES } & \text { Inductively Coupled Plasma-Atomic Emission Spectroscopy } \\ \text { LG\&E-KU } & \text { Louisville Gas \& Electric and Kentucky Utilities Company } \\ \text { PC } & \text { Portland Cement } \\ \text { S/S } & \text { Solidification/Stabilization } \\ \text { SCR } & \text { Selective Catalytic Reduction } \\ \text { TEOS } & \text { Tetraethyl Orthosilicate } \\ \text { TGA } & \text { Thermogravimetric Analysis } \\ \text { TMOS } & \text { Tetramethyl Orthosilicate } \\ \text { TSS } & \text { Total Suspended Solids } \\ \text { USEPA } & \text { United State Environmental Protection Agency } \\ \text { UV-Vis } & \text { ZLD }\end{array}$




\section{LIST OF TABLES}

TABLE 1: Summary of LG\&E-KU Trimble County Wastewaters................................. 7

TABLE 2: Structural Assignments of Raman Bands during TMOS Hydrolysis. ............ 13

TABLE 3: Structural Assignments of FT-IR Peaks in TMOS Condensation. ................. 16

TABLE 4: Ratios of Si-O-Si over Si-O-H Transmittances from Figure 7.a ................... 18 


\section{LIST OF FIGURES}

FIGURE 1: Depiction of Coal-Fired Waste Streams and Regulatory Standards.

FIGURE 2: Process Schematic for Solidification/Stabilization of Wastewaters using

Tetramethyl Orthosilicate (TMOS) ........................................................... 8

FIGURE 3: Process Schematic for Solidification/Stabilization of Wastewaters using

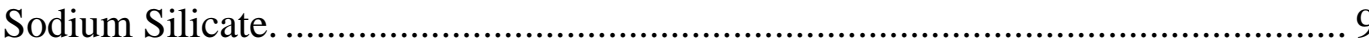

FIGURE 4: Raman Time Scan on the Hydrolysis of TMOS..................................... 14

FIGURE 5: FT-IR Time Scan on the Drying of TMOS/Wastewater Gels..................... 16

FIGURE 6: Encapsulated LG\&E-KU Wastewaters (1) Immediately After Gelation and

(2) After 20 Days of Drying with TMOS. ................................................... 17

FIGURE 7: (a) FT-IR Spectra and (b) TGA of Glass Monoliths Prepared with Three

LG\&E-KU Wastewaters and DI water. ................................................... 18

FIGURE 8: (a) EIS Detection of Salt Leaching Rate of CBAP and (b) FGD Wastewaters prepared Glass Monoliths.

FIGURE 9: (a) UV-Vis Detection of Chromium and (b) Copper Leaching from Glass Monoliths prepared at high concentrations (5000 ppm)................................. 20

FIGURE 11: Schematic Demonstrating Chemical Fixation Mechanism ....................... 24

FIGURE 12: Recommended Research Path towards the Industrialization of Sol-Gel

Encapsulation at Coal-Fired Power Plants.................................................... 27

FIGURE 13: Research Proposals for Enhancing Solidification/Stabilization Technologies with Sol-Gel Treatment.......................................................................... 28 
I. INTRODUCTION 
The treatment of wastewaters containing heavy metals is a new and expensive challenge for coal-fired power generation. In recent years the United States Environmental Protection Agency (USEPA) has enacted or revised regulations, that requires safe disposal of Coal Combustion Residuals (CCRs) and set federal limits on toxic metals in wastewaters discharged from power plants. $[1,2]$ The majority of regulations on coalfired wastewaters stem from the USEPA's Effluent Limitation Guidelines and Standards for the Steam Electric Power Generating Point Source Category, commonly referred to as ELG.

In 2015, revisions to the ELG rule required many coal-fired power plants to build new waste management equipment and significantly change operations; in other cases, coalfired generating units retired early. Modern day ELG regulations have been summarized in Figure 1 below. [2] The most impactful changes in 2015 were the zero-liquid discharge requirements on coal bottom ash, coal fly ash, and flue gas mercury control wastes. Further, the effluent discharge limits on flue gas desulfurization (FGD) wastewater were tightened and many low-volume waste streams were reclassified to high-volume waste streams with more strict standards. Regulations on coal pile runoff, low volume wastewaters, and non-chemical metal cleaning wastes were unchanged by the new ELG rule. The USEPA cited insufficient or hard to interpret data as the reason for not regulating those particular waste streams. [3] 


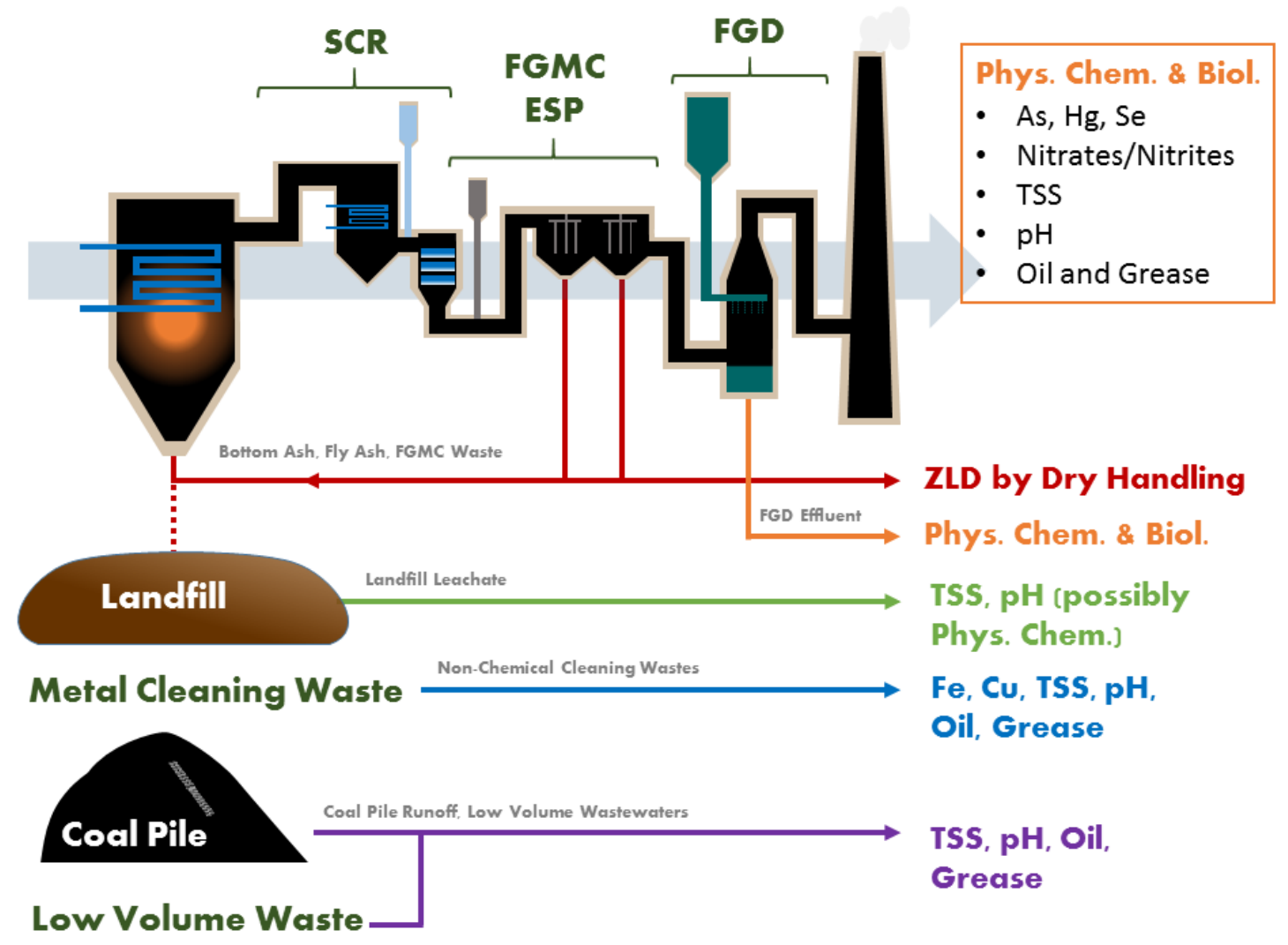

FIGURE 1: Depiction of Coal-Fired Waste Streams and Regulatory Standards.[3]

As electric utilities across the United States improve their processes to meet these regulations, many compliance scenarios require the use of zero-liquid discharge (ZLD) technologies. Driven by the desire to preclude pollution of scarce freshwater resources, ZLD wastewater management strategies are growing in global popularity. [4] Meeting the demands for ZLD wastewater management has led to widespread investigation and implementation of heavy metal stabilization/solidification (S/S) techniques. Stabilization is the process of chemical fixation or adsorption of contaminants to the chemical structure of the solid. Solidification is the physical encapsulation of a contaminants 
within the solid form. [5] S/S immobilization methods typically fall under one of two categories: cementitious or thermal treatments.

Both cementitious and thermal S/S techniques have been extensively developed, studied, and reviewed for the last decades. Cementitious treatments encapsulate hazardous solids, sludges, and liquids with a binder. Portland cement, alkali-activated cement, and chemically bonded phosphate ceramic are three common binders. One prominent technology application is immobilization by geopolymerization using readily available aluminosilicate materials such as coal fly ash (CFA), slag, or silicate clay minerals. [6, 7] Thermal treatments include sintering or vitrification of a solid waste to produce a stabilized form. Vitrification is sometimes achieved by adding ceramic precursors to the solid waste to form a ceramic product. [5]

Stabilization/Solidification of hazardous waste streams for remedial or fixed treatment operations has been conducted within the U.S. for 40 years, but until recently treatment has focused outside the scope of coal-fired generation wastewaters. [8] The nuclear power industry has conducted and supported substantial work on S/S treatments on nuclear waste brines by cementitious and thermal $\mathrm{S} / \mathrm{S}$. Park established a vitrification method for S/S using soluble silicates, phosphoric acid, and additives that leached $0.72 \%$ and $0.014 \%$ of cesium and strontium, respectively. [9] Cementitious S/S treatment for nuclear waste using Portland Cement (PC), titanate fibers, and iron slag was developed by Saleh. [10] In 1999, the Department of Energy (DOE) investigated S/S of nuclear waste by sol-gel encapsulation. Tetraethylorthosilicate (TEOS) was used to solidify 
waste, and pores in the dried solids were infiltrated and filled with polyceram or resin solutions to increase resistance to leaching. [11]

Comparatively, there has been less research and development for S/S of coal-fired generation wastewaters. Renew proposed the treatment of concentrated flue gas desulfurization (FGD) brines with coal fly ash (CFA) by cementitious S/S using Portland Cement (PC). [12] One major challenge with cementitious S/S at coal-fired generation facilities is the large volume of encapsulated solids that must be stored within a landfill. Secondarily, cementitious methods have struggled with targeting some toxic metals commonly found within coal-fired wastewaters such as Arsenic, Chromium, Mercury and Selenium. [8] Vitrification methods are unfavorable for power generation because the process energy requirements significantly the impact parasitic load of the generation facility. In what follows, I propose treatment of various coal-fired generation wastewaters using sol-gel encapsulation as an alternative solution.

This thesis documents the novel development of sol-gel encapsulation methods by two different Silane precursors: (1) Tetramethyl Orthosilicate and (2) Sodium Silicate. Successful encapsulation of wastewaters with various $\mathrm{pH}$ and solids content has been demonstrated. Further, it will be shown that the encapsulation by sol-gel retained regulated metals chromium, copper, and mercury during leaching by up to $95 \%$. It is proposed that sol-gel encapsulation chemically fixates positively-charged contaminants to the negatively-charged silicate network. 
II. METHODS 
Materials. Coal-Fired Wastewaters. Three wastewater samples were collected at the Trimble County Generating Station of Louisville Gas \& Electric and Kentucky Utilities Company (LG\&E-KU). The Trimble County Generating Station operates two pulverized coal-fired units and six combustion turbines. The first sample was collected from the purge stream of the flue-gas desulfurization scrubber. The second sample was collected from the bottom ash pond. The third sample was collected from the effluent of a natural gas fired flash evaporator used to the concentrate the bottom ash pond wastewater to approximately $30 \%$ total solids. Chemical properties of the wastewaters have been summarized in table 1 below.

TABLE 1: Summary of LG\&E-KU Trimble County Wastewaters.

\begin{tabular}{cccc}
\hline Sample & $\mathrm{pH}$ & $\begin{array}{c}\text { Total Solids } \\
(\%)\end{array}$ & $\begin{array}{c}\text { Conductivity a } \\
(\mu \mathrm{S} / \mathrm{m})\end{array}$ \\
\hline Flue Gas Desulfurization & 7.32 & 2.17 & 50300 \\
(FGD) & 8.07 & 0.01 & ----- \\
Bottom Ash Pond (BAP) & 31.36 & 361000 \\
$\begin{array}{c}\text { Concentrated Bottom Ash } \\
\text { Pond (CBAP) }\end{array}$ & 6.16 & 36 \\
\hline
\end{tabular}

${ }^{\mathrm{a}}$ Conductivity of a $20 \%(\mathrm{v} / \mathrm{v})$ Mixture with DI Water.

Mock Wastewaters. Mock wastewaters were prepared for ICP-AES analysis to eliminate geological interference signals observed in LG\&E-KU samples leading to improved detection capabilities. Reagent grade Chromium (III) Acetate, Copper (II) Acetate, Mercury (II) Chloride, and Sodium Selenate were dissolved in DI water to create high (5000 ppm) and low (4 - 8 ppm) concentration solutions of wastewaters. 
Other. Tetramethyl Orthosilicate (TMOS, >98\%) was acquired from Sigma-Aldrich (Sigma-Aldrich, St. Louis, MO). ICP standard solutions of Chromium, Copper, Mercury and Selenium in a Nitric Acid matrix were acquired from Inorganic Ventures (Inorganic Ventures, Christiansburg, VA). Water was twice distilled and deionized to a specific resistance of $18.2 \mathrm{M} \Omega-\mathrm{cm}$.

Tetramethyl Orthosilicate Sol-gel Process. Tetramethyl Orthosilicate was hydrolyzed in DI water by heating with microwave irradiation at a power of $1000 \mathrm{~W}$ for 15 seconds. The solution was mixed using a vortex mixer periodically for 20 minutes or until the solution was homogenous and clear. A wastewater sample was combined in equivalent proportions with the TMOS sol. Upon combination, the gels were dried for 20 days at ambient conditions $\left(21^{\circ} \mathrm{C}, 1 \mathrm{~atm}\right)$. Figure 2 demonstrates the process for preparing wastewater glass monoliths with Tetramethyl Orthosilicate.
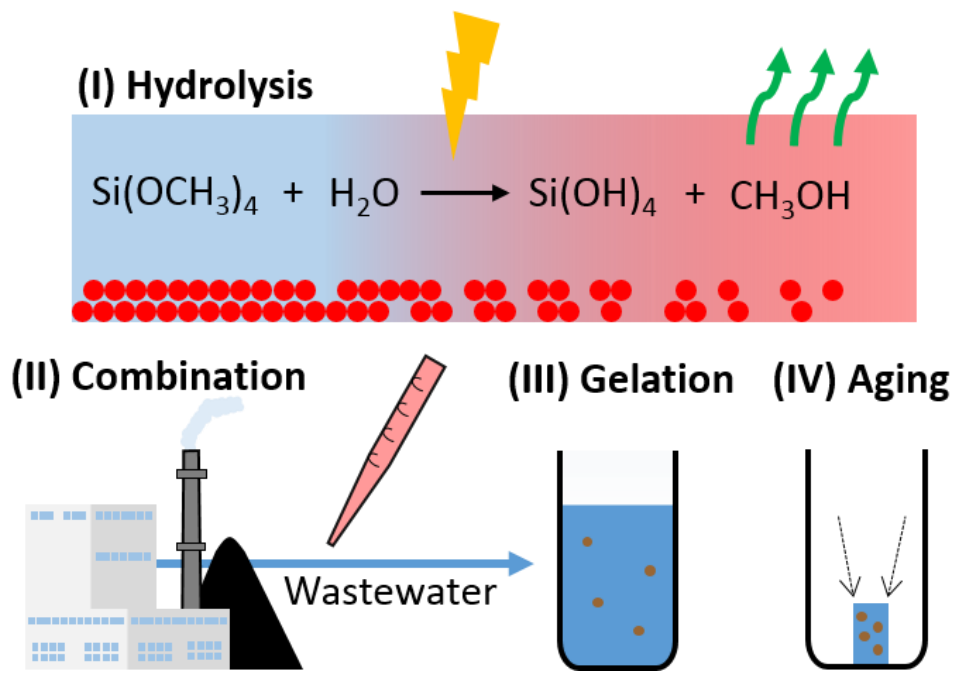

FIGURE 2: Process Schematic for Solidification/Stabilization of Wastewaters using Tetramethyl Orthosilicate (TMOS). 
Sodium Silicate Sol-gel Process. Wastewater and Sodium Silicate were combined and continuously agitated. Hydrochloric Acid was added to the solution to reduce solution $\mathrm{pH}$ to 9. An example $\mathrm{pH}$ adjustment calculation is demonstrated in Appendix A. The combination of wastewater, Sodium Silicate and Hydrochloric Acid was agitated for an additional 10 minutes and then set aside for gelation and drying at ambient conditions (21 ${ }^{\circ} \mathrm{C}, 1 \mathrm{~atm}$ ). Figure 3 demonstrates the process for preparing wastewater glass monoliths with Sodium Silicate.

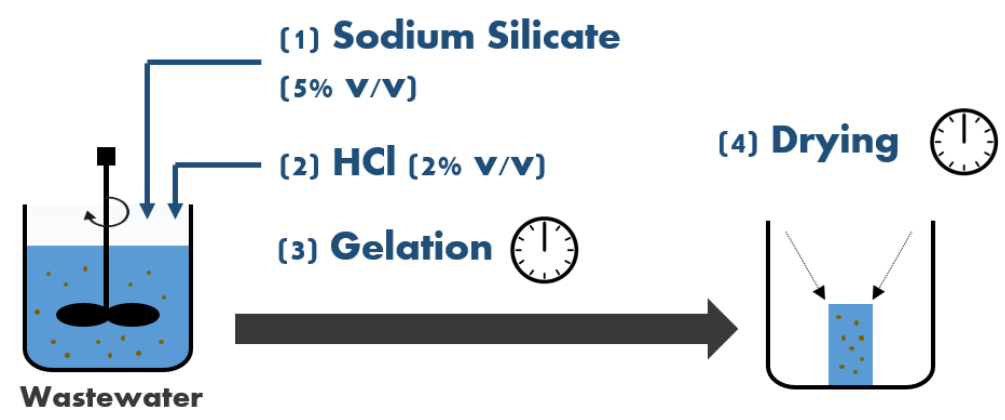

FIGURE 3: Process Schematic for Solidification/Stabilization of Wastewaters using Sodium Silicate.

Characterization. Raman Spectroscopy. Raman Spectra from 100 to $3200 \mathrm{~cm}^{-1}$ were collected with a MarqMetrix WAIO spectrometer (MarqMetrix, Seattle, WA). The spectra were excited with $450 \mathrm{~mW}$ using a collimated laser beam at $785 \mathrm{~nm}$ and obtained by averaging 10 scans at $400 \mathrm{~ms} / \mathrm{scan}$. Continuous agitation during analysis was achieved by placing a small magnetic stir plate on top of the spectrometer stage. 
Fourier-Transform Infrared Spectroscopy (FT-IR). FT-IR solid analyses were conducted with a Spectrum 100 spectrometer (Perkin Elmer, Waltham, MA). FT-IR spectra were recorded from 4000 to $650 \mathrm{~cm}^{-1}$ using a resolution of $4 \mathrm{~cm}^{-1}$ and 4 scans per sampling.

Thermal-Gravimetric Analysis (TGA). Thermal analysis data were collected using a SDT Q600 simultaneous TGA/DSC (TA Instruments, New Castle, DE). Ceramic samples cups were balanced by the SDT Q600 before loading one sample cup with approximately 18 $\mathrm{mg}$ of powdered sample. Samples were heated from ambient to $1000{ }^{\circ} \mathrm{C}$ at a heating rate of $20^{\circ} \mathrm{C} / \mathrm{min}$. The heating chamber was purged with nitrogen gas at a rate of $20 \mathrm{~mL} / \mathrm{min}$.

Electrochemical Impedance Spectroscopy (EIS). Resistances of samples and leachates were measured using an Autolab PGSTAT128N Potentiostat (Metrohm Autolab B.V., Ultrecht, Netherlands). Resistance was measured by applying $0.2 \mathrm{mV}$ at $0.1 \mathrm{MHz}$, taking the real part of the impendence at high frequency to be the resistance.

Leaching. Leaching for UV-Vis analyses were conducted by agitating one glass monolith (initial $1 \mathrm{~mL}$ of wastewater) in $4 \mathrm{~mL}$ of DI Water for 18 hours. Leaching for ICP-AES was conducted by agitating two glass monolith in $8 \mathrm{~mL}$ of DI Water for 24 hours. In both cases the leachate was separated from the glass monolith by pipetting the leachate from the extraction mixture. 
Ultraviolet-visible Spectroscopy (UV-Vis). Detection of chromium and copper leaching at high concentrations was measured by collecting UV-Vis spectra from 300 to $1000 \mathrm{~nm}$. Standard solutions were prepared to create a calibration curve used for the determination of concentration in the leachate.

Inductively Coupled Plasma Atomic Emission Spectroscopy (ICP-AES). Elemental analyses of leachates were conducted with an IRIS Intrepid II XSP Inductively Coupled Plasma Atomic Emission Spectrometer (Thermo Scientific, Waltham, MA). Mercury detection was completed by reduction to $\mathrm{Hg}(0)$ using Stannous Chloride and an HGX200 Cold Vapor system (Teledyne CETAC Technologies, Omaha, NE). 
III. RESULTS AND DISCUSSION 


\section{Process Characterization}

The progression of Tetramethyl Orthosilicate (TMOS) hydrolysis was monitored by Raman spectroscopy and the results shown in figure 4 indicate full hydrolysis to Silicic Acid. Band assignments are summarized in table 2. It has been shown that the TMOS peak at $646 \mathrm{~cm}^{-1}$ disappeared entirely 20 minutes post microwave irradiation. The methanol peak at $1029 \mathrm{~cm}^{-1}$ successively rose and slowed to a near plateau after 20 minutes. Intermediate peaks for partially hydrolyzed species at $673 \mathrm{~cm}^{-1}, 697 \mathrm{~cm}^{-1}$, and $725 \mathrm{~cm}^{-1}$ were all shown to rise, reach their peak sequentially, and fall, confirming that TMOS hydrolysis occurs in four mechanistic steps shown in the equations below.

Overall

$$
\begin{aligned}
& \mathrm{Si}\left(\mathrm{OCH}_{3}\right)_{4}+4 \mathrm{H}_{2} \mathrm{O} \rightarrow \mathrm{Si}(\mathrm{OH})_{4}+4 \mathrm{CH}_{3} \mathrm{OH} \\
& \mathrm{Si}\left(\mathrm{OCH}_{3}\right)_{4}+\mathrm{H}_{2} \mathrm{O} \rightarrow \mathrm{Si}\left(\mathrm{OCH}_{3}\right)_{3}(\mathrm{OH})+\mathrm{CH}_{3} \mathrm{OH} \\
& \mathrm{Si}\left(\mathrm{OCH}_{3}\right)_{3}(\mathrm{OH})+\mathrm{H}_{2} \mathrm{O} \rightarrow \mathrm{Si}\left(\mathrm{OCH}_{3}\right)_{2}(\mathrm{OH})_{2}+\mathrm{CH}_{3} \mathrm{OH} \\
& \mathrm{Si}\left(\mathrm{OCH}_{3}\right)_{2}(\mathrm{OH})_{2}+\mathrm{H}_{2} \mathrm{O} \rightarrow \mathrm{Si}\left(\mathrm{OCH}_{3}\right)(\mathrm{OH})_{3}+\mathrm{CH}_{3} \mathrm{OH} \\
& \mathrm{Si}\left(\mathrm{OCH}_{3}\right)(\mathrm{OH})_{3}+\mathrm{H}_{2} \mathrm{O} \rightarrow \mathrm{Si}(\mathrm{OH})_{4}+\mathrm{CH}_{3} \mathrm{OH}
\end{aligned}
$$

TABLE 2: Structural Assignments of Raman Bands during TMOS Hydrolysis.[13, 14]

\begin{tabular}{cc}
\hline Intermediate & Raman Shift $\left(\mathrm{cm}^{-1}\right)$ \\
\hline $\mathrm{Si}\left(\mathrm{OCH}_{3}\right)_{4}$ & 646 \\
$\mathrm{Si}\left(\mathrm{OCH}_{3}\right)_{3}(\mathrm{OH})$ & 673 \\
$\mathrm{Si}\left(\mathrm{OCH}_{3}\right)_{2}(\mathrm{OH})_{2}$ & 697 \\
$\mathrm{Si}\left(\mathrm{OCH}_{3}\right)(\mathrm{OH})_{3}$ & 725 \\
$\mathrm{Si}(\mathrm{OH})_{4}$ & 750 \\
$\mathrm{CH}_{3} \mathrm{OH}$ & 1029 \\
\hline
\end{tabular}




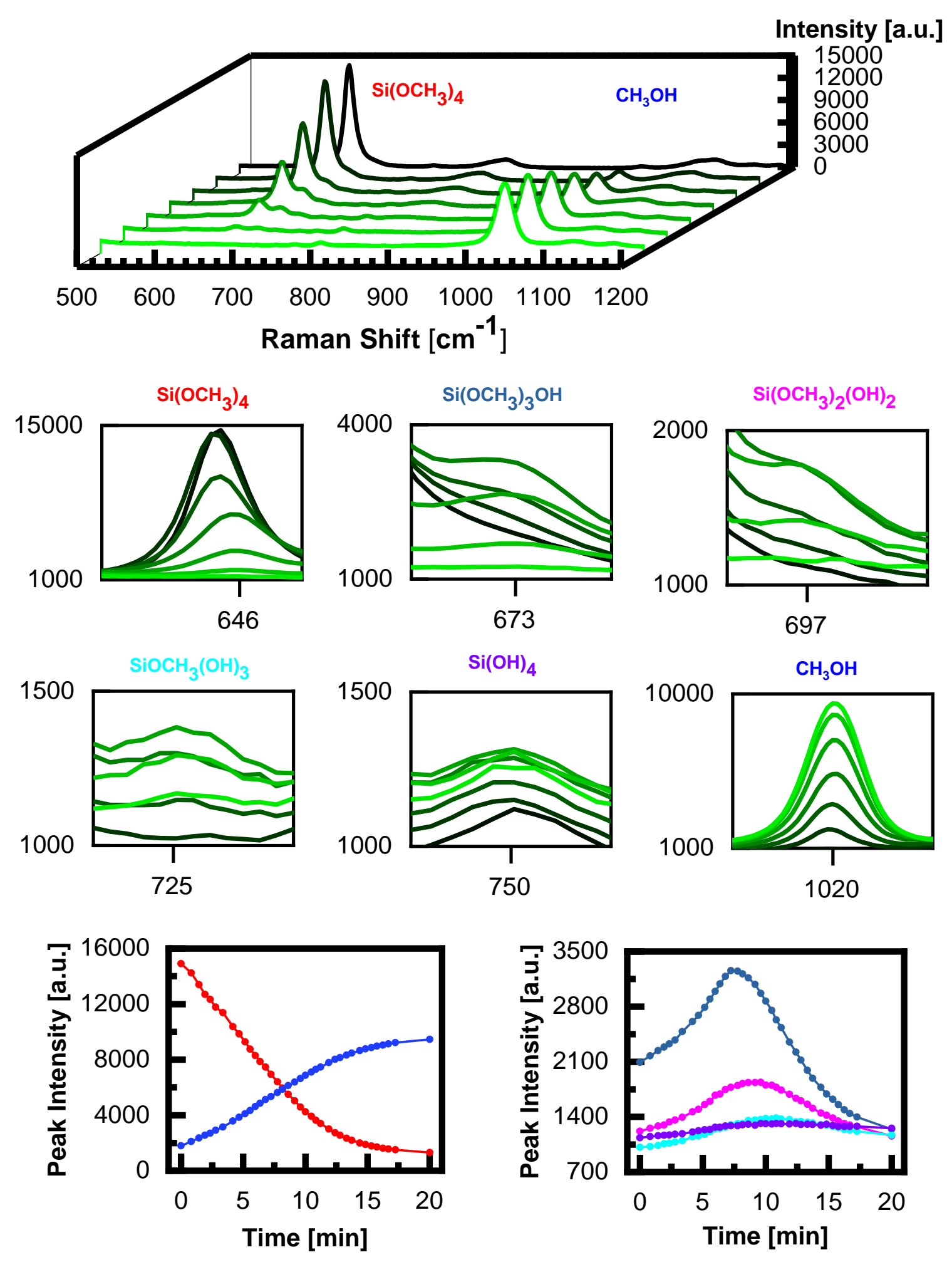

FIGURE 4: Raman Time Scan on the Hydrolysis of TMOS. 
The condensation of Silicic Acid mixed with wastewaters was monitored by Fourier Transform-Infrared Spectroscopy (FT-IR), and all results showed the formation of an expansive Silicon Dioxide network. Selected condensation results are summarized in figure 5. Condensation of Silicic Acid (prepared with TMOS) can occur in two ways: (1) the reaction of two Silanol groups to produce a Silicon Dioxide dimer and water, or (2) the reaction of one Silanol group and one Methyl group to produce a Silicon Dioxide dimer and Methanol. Both reaction condensation mechanisms are summarized by equations 6 and 7.

$$
\begin{gathered}
2(\equiv \mathrm{Si}-\mathrm{OH}) \rightarrow \equiv \mathrm{Si}-\mathrm{O}-\mathrm{Si} \equiv+\mathrm{H}_{2} \mathrm{O} \\
\equiv \mathrm{Si}-\mathrm{OH}+\equiv \mathrm{Si}-\mathrm{OCH}_{3} \rightarrow \equiv \mathrm{Si}-\mathrm{O}-\mathrm{Si} \equiv+\mathrm{CH}_{3} \mathrm{OH}
\end{gathered}
$$

FT-IR structural assignments for water, Silicon Dioxide, and Silanol groups have been summarized in table 3 . Figure 3 illustrates the drying of glass monoliths during a period of 20 days. After 20 days, water peaks at 3300 and 1638 nanometers disappear. The condensation and development of the a Silicon Dioxide network occurs within the first few days of drying as is indicated by the large Silicon Dioxide peak at $1080 \mathrm{~cm}^{-1}$ in both samples. 
TABLE 3: Structural Assignments of FT-IR Peaks in TMOS Condensation.[15-18]

\begin{tabular}{cc}
\hline Peak Assignment & Band Position $\left(\mathrm{cm}^{-1}\right)$ \\
\hline $\mathrm{H}-\mathrm{O}-\mathrm{H}\left(v_{\mathrm{s}}, v_{\mathrm{as}}\right)$ & 3300 \\
$\mathrm{H}-\mathrm{O}-\mathrm{H}(\delta)$ & 1638 \\
$\mathrm{Si}-\mathrm{O}-\mathrm{Si}\left(v_{\mathrm{as}}\right)$ & 1080 \\
$\mathrm{Si}-\mathrm{O}-\mathrm{H}\left(v_{\mathrm{s}}\right)$ & 940 \\
$\mathrm{Si}-\mathrm{O}-\mathrm{Si}\left(v_{\mathrm{s}}\right)$ & 750 \\
\hline
\end{tabular}

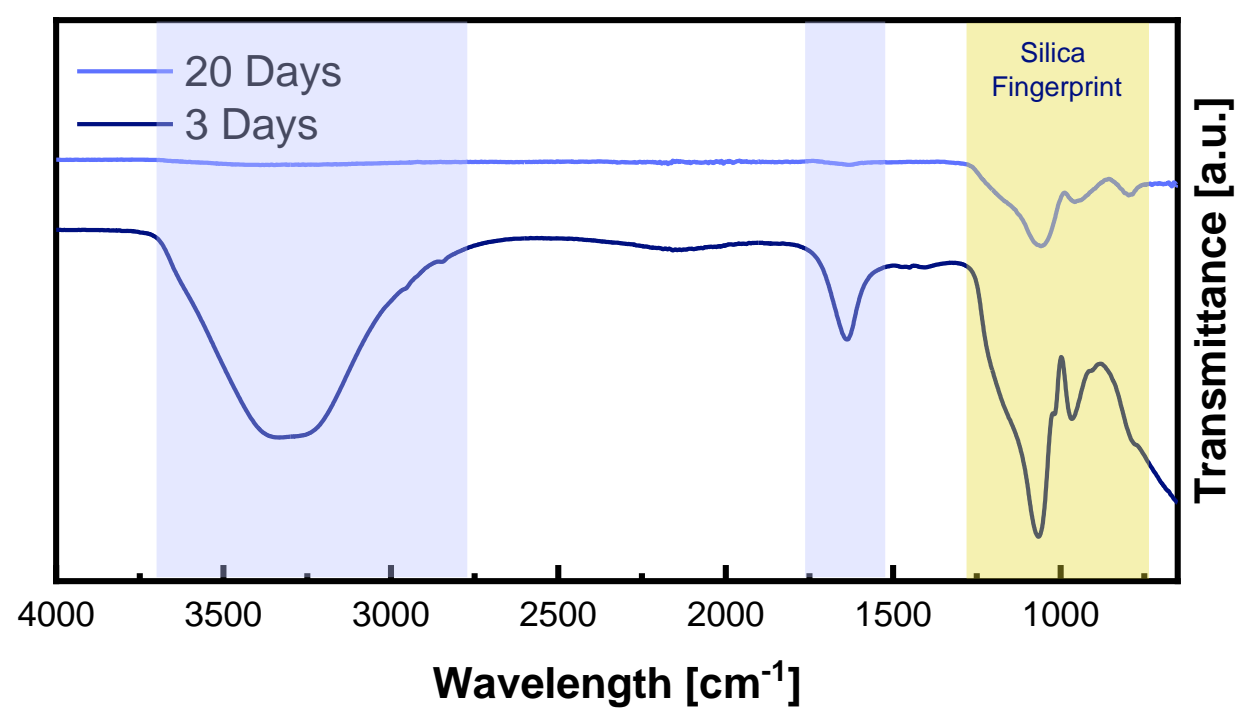

FIGURE 5: FT-IR Time Scan on the Drying of TMOS/Wastewater Gels.

\section{Material Characterization}

All wastewater samples provided by LG\&E-KU were successfully encapsulated by solgel processing with TMOS. Properties varied between samples, but no solidification issues arose when encapsulating samples. Gelation occurred quickest for concentrated bottom ash pond (CBAP) samples and slowest for DI water samples, corresponding to external claims that rate of gelation is proportional to salt concentration and inversely 
proportional to $\mathrm{pH}$. $[13,19,20]$ Stratification of salts was observed in glass monoliths prepared with CBAP and FGD wastewaters as observed in figure 6. Volume reduction of the glass monolith was observed, and the theoretical volume reduction is calculated in Appendix A.

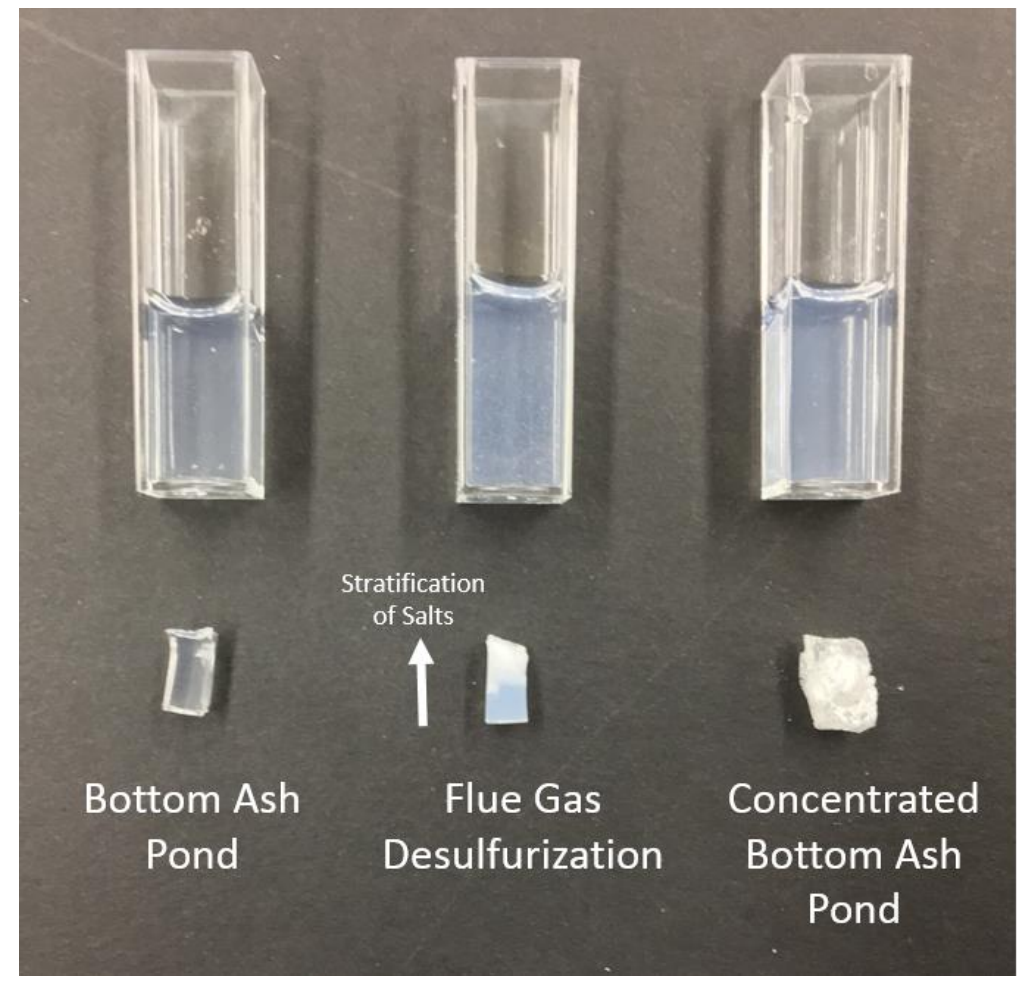

FIGURE 6: Encapsulated LG\&E-KU Wastewaters (1) Immediately After Gelation and (2) After 20 Days of Drying with TMOS.

Figure 7.a shows FT-IR spectra for glass monoliths prepared with LG\&E-KU samples after 20 days of drying. All samples had similar Silicon Dioxide to Silanol peak ratios as shown in table 4, indicating that development of the Silicon Dioxide network was not hindered by the wastewater constituency. The FT-IR spectra for concentrated bottom ash pond (CBAP) wastewater showed large signals for stretching and bending of water 
molecules at 3300 and $1638 \mathrm{~cm}^{-1}$, indicating significant retention of water. TGA of the CBAP samples confirmed higher retention of water compared to the other LG\&E-KU samples. In figure 7.b, it was observed that CBAP samples had two water peaks indicating the dehydration of free and bound water. Bound water can be caused by hydration of salts leading to boiling point elevation. Salts are present in high concentrations for CBAP samples.
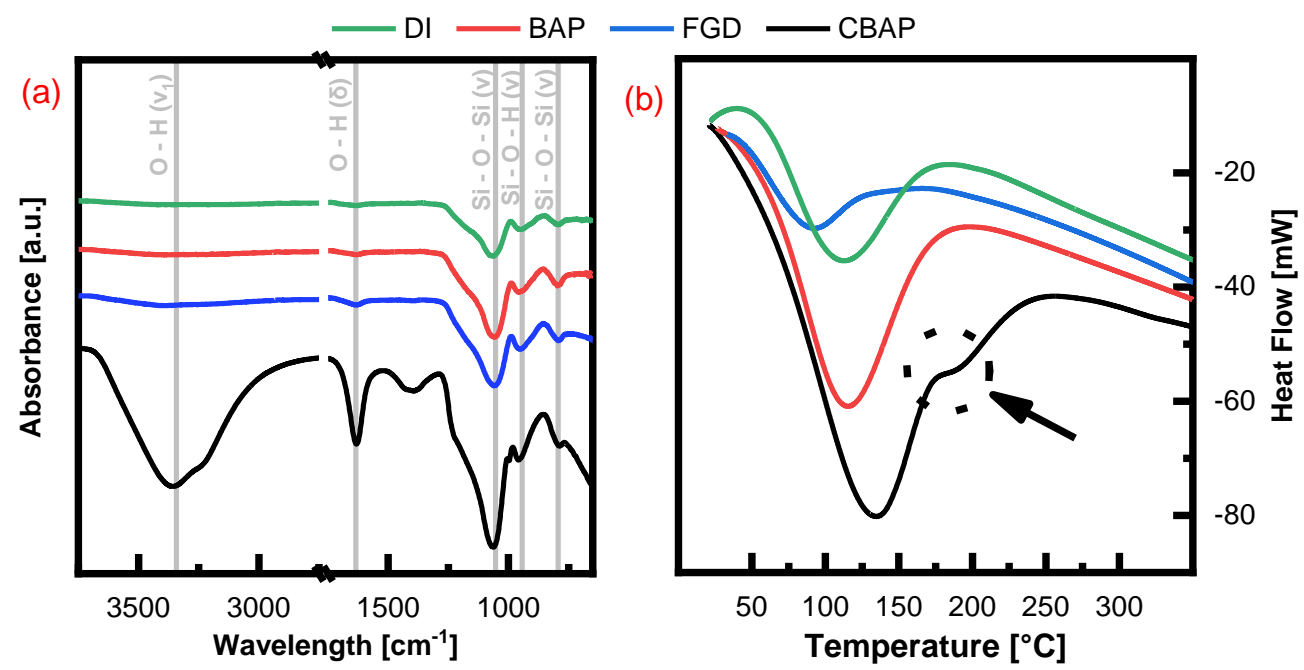

FIGURE 7: (a) FT-IR Spectra and (b) TGA of Glass Monoliths Prepared with Three LG\&E-KU Wastewaters and DI water.

TABLE 4: Ratios of Si-O-Si over Si-O-H Transmittances from Figure 7.a

\begin{tabular}{lccc}
\hline & Si-O-Si $\left(1080 \mathrm{~cm}^{-1}\right)$ & Si-O-H $\left(940 \mathrm{~cm}^{-1}\right)$ & Peak Ratio \\
& Transmittance [a.u.] & Transmittance [a.u.] & \\
\hline CBAP & 42.41 & 24.12 & 1.76 \\
BAP & 13.35 & 8.90 & 2.06 \\
FGD & 18.52 & 10.81 & 1.71 \\
DI & 11.25 & 5.66 & 1.99 \\
\hline
\end{tabular}




\section{Leaching Characterization}

Leaching of ionically charged species, which was measured by electrochemical impedance spectroscopy, is summarized in figure 8 . At time zero, resistance of the DI water was detected. Upon introducing the glass monolith to the DI water after time zero, resistance immediately plummeted to near the resistance of an equivalently diluted wastewater/DI water mixture. After less than 5 minutes, the resistance of the solution leveled indicating equilibrium of salt leaching.
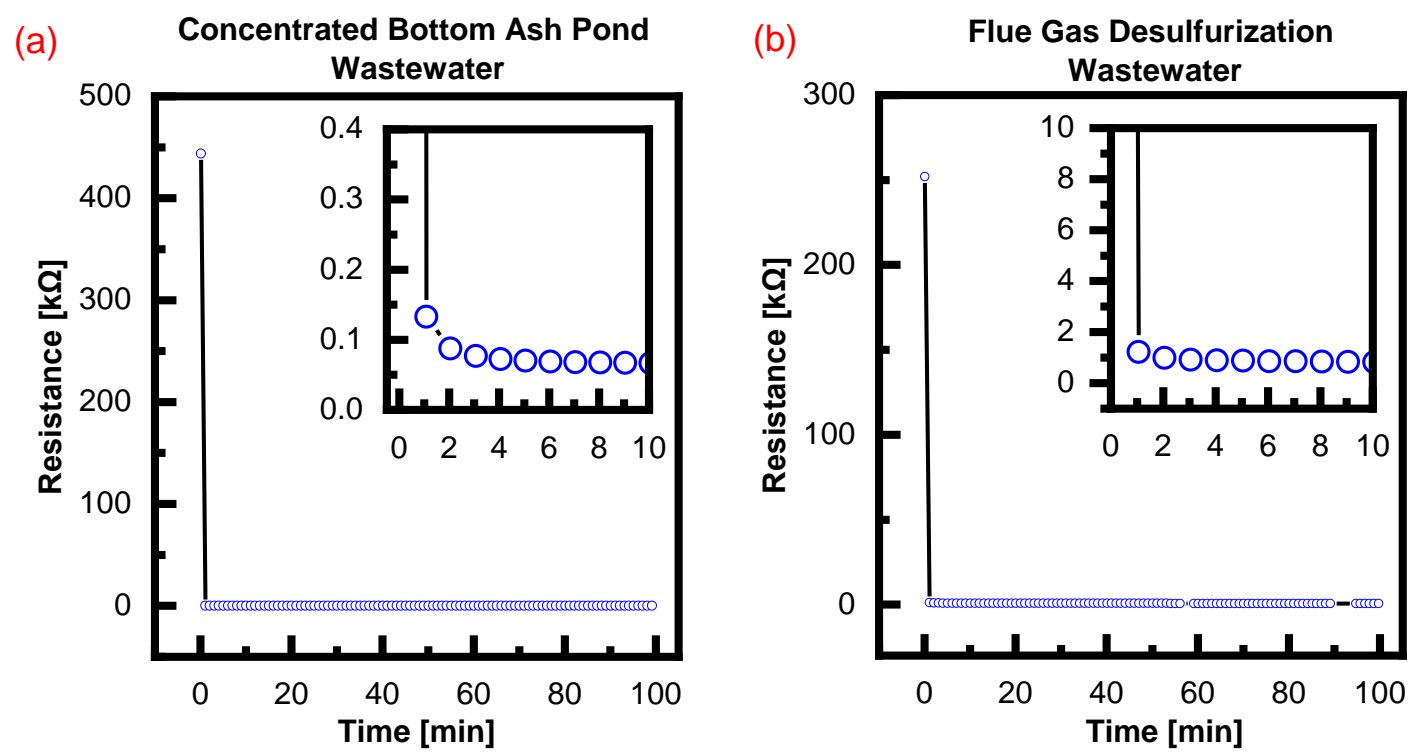

FIGURE 8: (a) EIS Detection of Salt Leaching Rate of CBAP and (b) FGD Wastewaters prepared Glass Monoliths.

Measurements by UV-Vis indicated retention of $40-50 \%$ for copper and chromium as shown in figure 9.a and 9.b for wastewaters at high contaminant concentrations. 

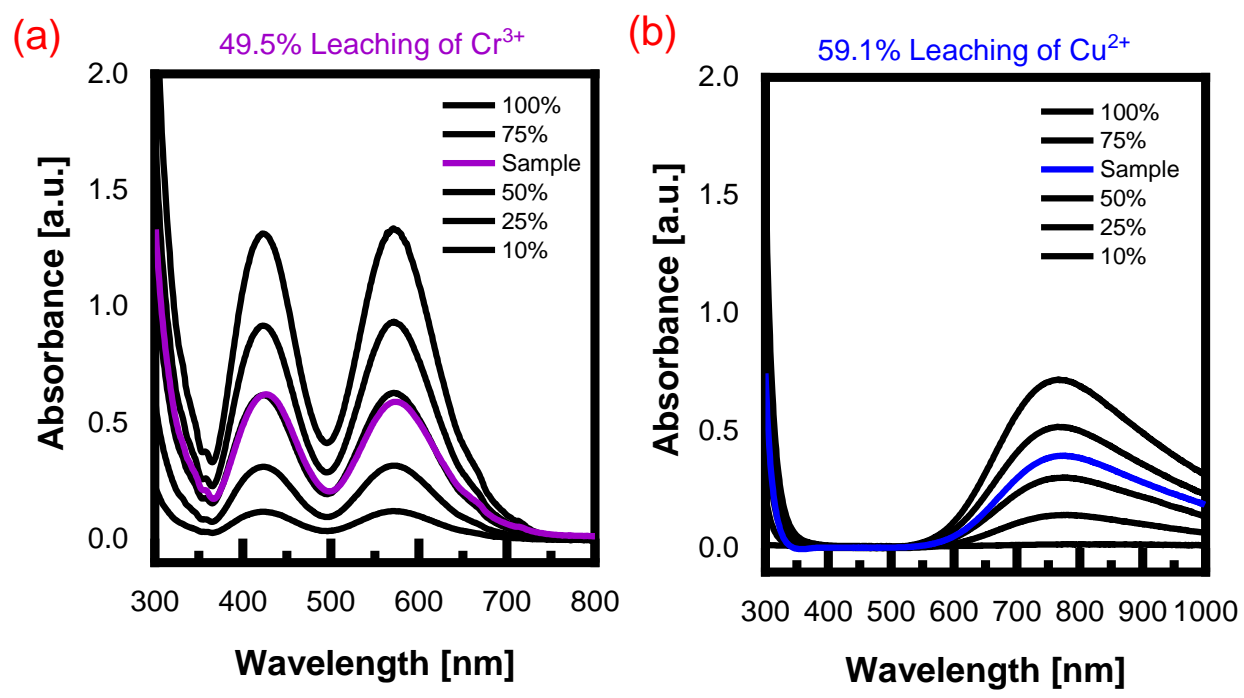

FIGURE 9: (a) UV-Vis Detection of Chromium and (b) Copper Leaching from Glass Monoliths prepared at high concentrations (5000 ppm).

ICP-AES detection of low concentration wastewater samples indicated better retention for all positively-charged species. Chromium, Copper, and Mercury were retained between $74-95 \%$ as summarized in figure 10 . Only $2 \%$ retention of negatively-charged Selenium (as $\mathrm{SeO}_{4}{ }^{2-}$ ) was retained by the glass, indicating nearly all selenium leached into solution during the 24-hour leaching period. Retention for low concentration samples was better across the board. It is hypothesized that chemical fixation of positivelycharged species to the negatively-charged Silicon Dioxide network is responsible for the retention of those elements. Further, it is hypothesized that at high contaminant, concentrations the available sites for chemical fixation are flooded, allowing fewer species to strongly fixate to the silicon dioxide network. Figure 11 depicts the hypothesized mechanism for chemical fixation of contaminants. 


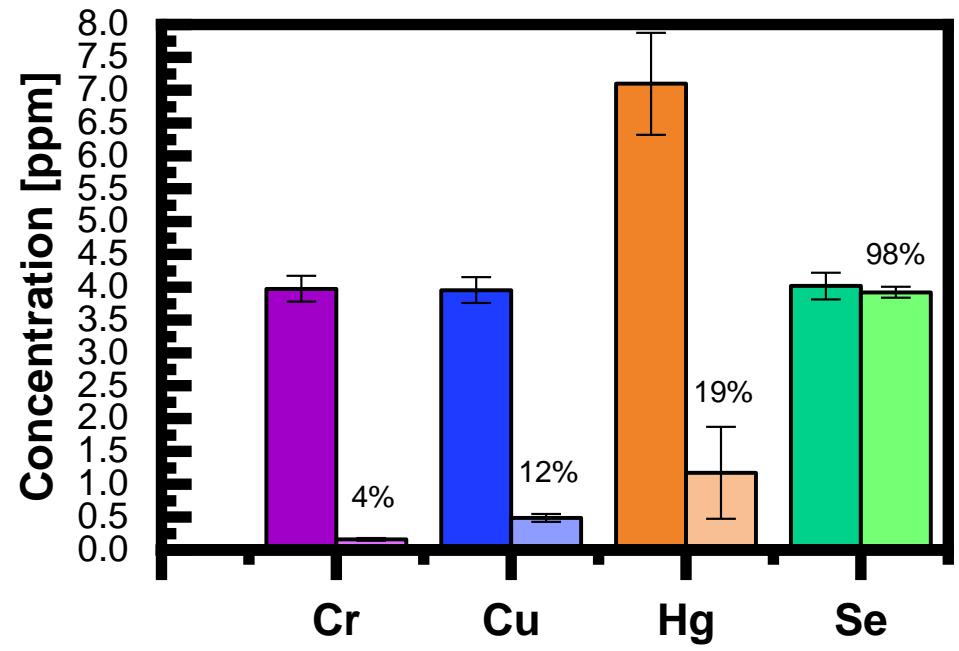

FIGURE 10: ICP-AES detection of Chromium, Copper, Mercury, and Selenium Leaching from Glass Monoliths. 
IV. CONCLUSIONS 
It has been shown that a novel sol-gel encapsulation method has been developed using Silane precursor Tetramethyl Orthosilicate (TMOS). LG\&E-KU wastewaters covered a spectrum of total solids content and chemical composition but all were successfully solidified. Encapsulation occurred in two-steps: (1) twenty minutes for hydrolysis of Tetramethyl Orthosilicate, and (2) combination of the sol with wastewater. Upon combination, gelation occurred quickly and was dependent upon the $\mathrm{pH}$ and solids content of the wastewater sample. Volume reduction occurred in all samples, but the retention of water led to less volume reduction for CBAP samples.

When placed in solution, leaching of ionically charged species and fracturing of the glass monoliths was observed. However, the products of sol-gel treatment demonstrated significant leach resistance for positively-charged metals Chromium, Copper and Mercury. All three species tested were retained by $74-95 \%$ after leaching in DI water for one day (contaminant concentrations near real LG\&E-KU wastewaters). Only $2 \%$ of negatively-charged selenium (as $\mathrm{SeO}_{4}{ }^{2-}$ ) was retained by the glass post leaching. The glass monoliths fractured into multiple fragments upon introduction to water indicating high porosity and minimal structural integrity. It has, therefore, been hypothesized that the mechanism for retention is chemical fixation of positively-charged species to the negatively charged silicate network as shown in figure 11. Retention rates were observed to be higher for wastewater solutions at low concentrations; therefore, it is hypothesized that at high concentrations of contamination, sites for chemical fixation are flooded leading to worsened rates of retention. 

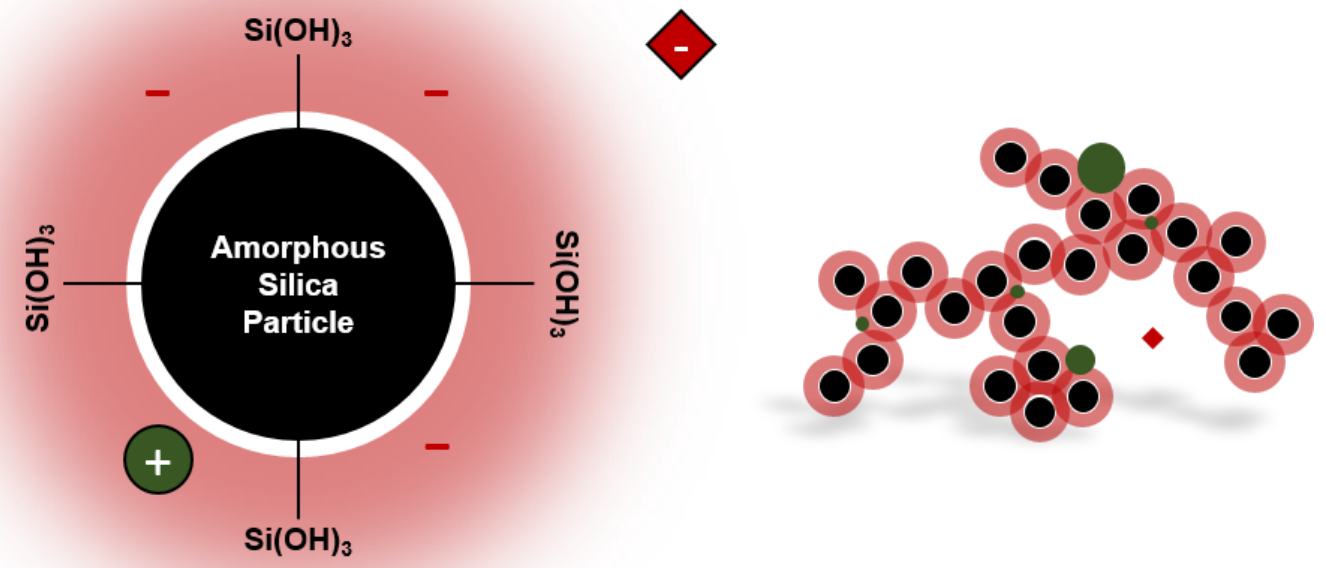

FIGURE 11: Schematic Demonstrating Chemical Fixation Mechanism

Based on the conclusions of this report, several recommendations for future research were made in the following section. 
V. RECOMMENDATIONS 
As has been shown, sol-gel encapsulation by Silane precursors can successfully solidify and stabilize positively-charged contaminants, but in order for the treatment to be successful within the coal-fired generation sector, solutions for retaining negativelycharged contaminants must be developed. Future research should focus on developing solutions that encapsulate both positively- and negatively-charged contaminants. One proposal for future research is to dose bulk Silane solutions (Tetramethyl Orthosilicate or Sodium Silicate) with additional Silane precursors that have chelating functional groups which would target regulated contaminants. Example functional groups include Thiols, Amines, and Ethylenediaminetetraacetic Acid (EDTA).

Future research could also focus on reducing the cost of treatment to compete with existing physical-chemical and biological wastewater treatment technologies. Sodium Silicate is the ideal Silane for cost competitiveness because it can be recovered directly from another coal-fired power plant waste: coal fly ash (CFA). Recovery of Silicates and Aluminates from Coal Fly Ash has been described by Qin Jinguo and Gu Songqing. [21, 22] In a multi-step process, Sodium Silicate is recovered by caustic leaching and concentration by vaporization, and Aluminates are recovered by alkali or acid leaching. Incorporation of CFA recovery and Sodium Silicate sol-gel encapsulation would be an economically favorable solution for wastewater management because:

- Recovered Aluminates could be sold to generate revenue

- Sodium Silicate would be readily available from unmarketable CFA

- Sodium Silicate would not require extensive purification if used for sol-gel wastewater encapsulation 
Figure 10 illustrates a research path towards an industrially ready sol-gel encapsulation solution. Steps in green have been achieved during the work of this thesis.

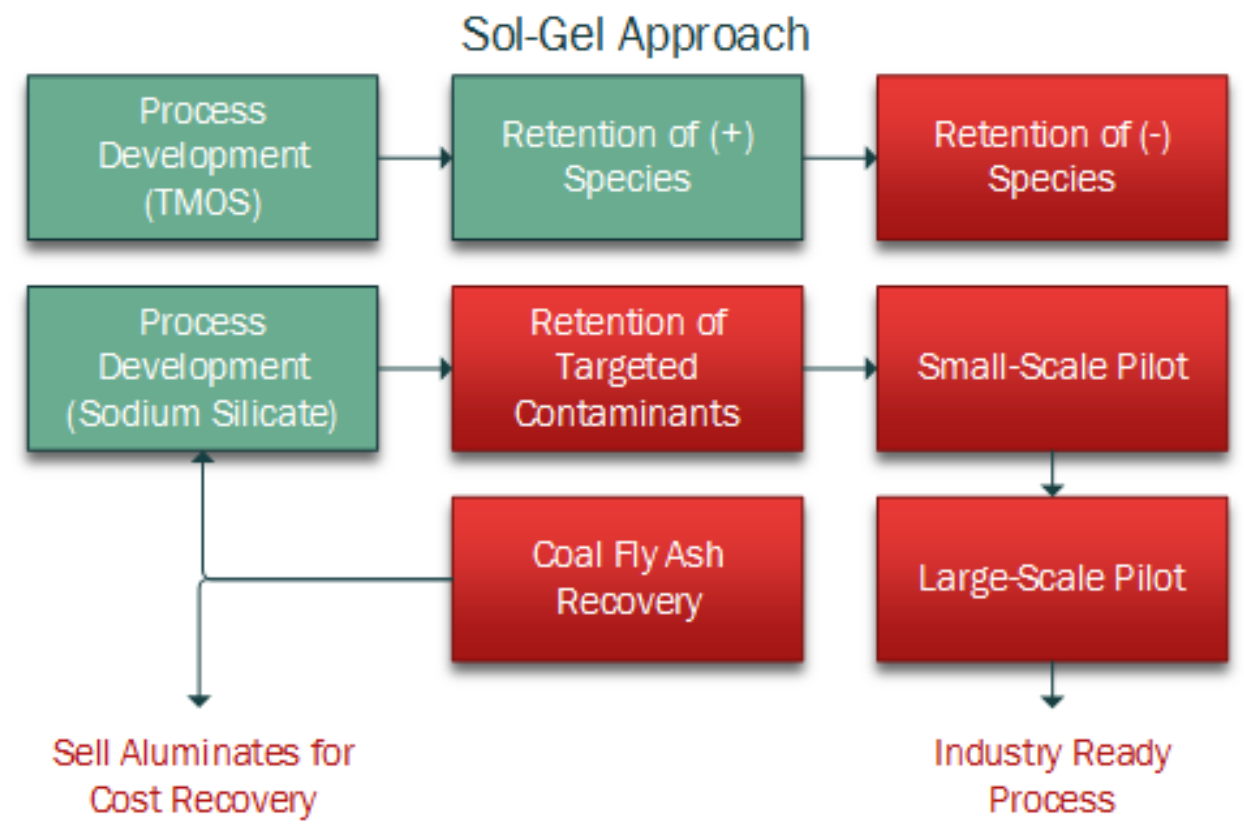

FIGURE 12: Recommended Research Path towards the Industrialization of Sol-Gel Encapsulation at Coal-Fired Power Plants.

Outside a purely sol-gel approach, research can focus on expanding other S/S technologies by incorporating sol-gel encapsulation. Figure 13 outlines two paths for the improvement of existing technologies. As shown in part (a), sol-gel pretreatment could be examined by dosing small concentrations of Silanes with wastewaters prior to encapsulation with cementitious binders. The objective of sol-gel pretreatment would be to chemically fixate target contaminants before solidification in a cementitious product. Part (b) demonstrates sol-gel treatment coupled with resin/polymer coating as originally examined by the DOE with high concentration salt wastes. [11] This method would be 
best suited for high concentration wastes or wastes where salt retention during leaching is important.

\section{Solidification/Stabilization Enhancements}

(a)

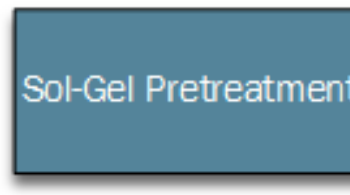

(b)

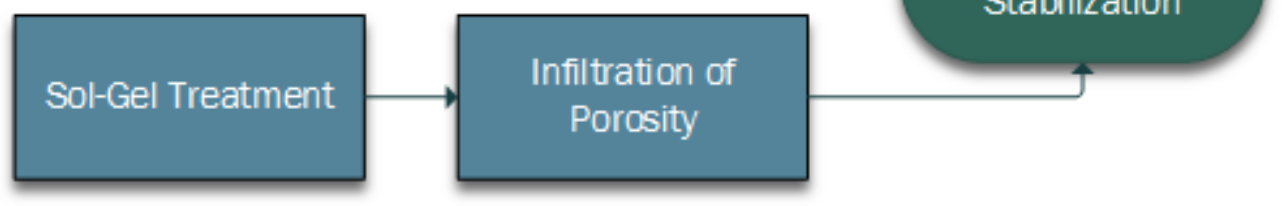

Cementitious

Encapsulation

Solidification/

Stabilization

FIGURE 13: Research Proposals for Enhancing Solidification/Stabilization

Technologies with Sol-Gel Treatment. 
REFERENCES 
1. Environmental Protection Agency, Hazardous and Solid Waste Management System; Disposal of Coal Combution Residuals from Electric Utilities, E.P. Agency, Editor. 2015. p. 201.

2. Environmental Protection Agency, Effluent Limitations Guidelines and Standards for the Steam Electric Power Generating Point Source Category, E.P. Agency, Editor. 2015. p. 67.

3. Environmental Protection Agency, Technical Development Document for the Effluent Limitations Guidelines and Standards for the Steam Electric Power Generating Point Source Category, E.P. Agency, Editor. 2015.

4. Tong, T. and M. Elimelech, The Global Rise of Zero Liquid Discharge for Wastewater Management: Drivers, Technologies, and Future Directions. Environmental Science \& Technology, 2016. 50(13): p. 6846-6855.

5. Guo, B., et al., The mechanisms of heavy metal immobilization by cementitious material treatments and thermal treatments: A review. Journal of Environmental Management, 2017. 193: p. 410-422.

6. $\quad \mathrm{Vu}, \mathrm{T}$. and $\mathrm{N}$. Gowripalan, Mechanisms of Heavy Metal Immobilisation using Geopolymerisation Techniques - A review. Vol. 16. 2018. 124-135.

7. Xu, J.Z., et al., Study on the factors of affecting the immobilization of heavy metals in fly ash-based geopolymers. Materials Letters, 2006. 60(6): p. 820-822.

8. Conner, J.R., Guide to improving the effectiveness of cement-based stabilization/solidification. 1997: Portland Cement Association.

9. Park, H.-S., et al., Stabilization/Solidification of Radioactive Molten Salt Waste via Gel-Route Pretreatment. Environmental Science \& Technology, 2007. 41(4): p. 1345-1351.

10. Saleh, H.M., et al., Mechanical and physical characterization of cement reinforced by iron slag and titanate nanofibers to produce advanced containment for radioactive waste. Construction and Building Materials, 2019. 200: p. 135145.

11. Smith, G.L.Z., Brian J., Stabilize High Salt Content Waste Using Sol Gel Process. 1999, Office of Environmental Management, Office of Science and Technology: U.S Department of Energy.

12. Renew, J.E., et al., Immobilization of Heavy Metals by Solidification/Stabilization of Co-Disposed Flue Gas Desulfurization Brine and Coal Fly Ash. Energy \& Fuels, 2016. 30(6): p. 5042-5051.

13. Brinker, C.J., Sol-gel science: the physics and chemistry of sol-gel processing, ed. G.W. Scherer and C.J. Brinker. 1990, Boston: Academic Press.

14. Lippert, J.L., S.B. Melpolder, and L.M. Kelts, Raman spectroscopic determination of the $\mathrm{pH}$ dependence of intermediates in sol-gel silicate formation. Journal of Non-Crystalline Solids, 1988. 104(1): p. 139-147.

15. Lappi, S., B. Smith, and S. Franzen, Infrared Spectra of H216O, H218O and D2O in the Liquid Phase by Single-Pass Attenuated Total Internal Reflection Spectroscopy. Vol. 60. 2004. 2611-9.

16. Niedziolka, J., et al., Characterisation of gold electrodes modified with methyltrimethoxysilane and (3-mercaptopropyl) trimethoxysilane sol-gel processed films. Journal of Electroanalytical Chemistry, 2005. 578(2): p. 239-245. 
17. O“ye, G., et al., Hydrolysis and condensation rates of tetramethyl orthosilicate in alcohol solutions of hydrated metal salts as determined by means of FT-IR spectroscopy. Colloids and Surfaces A: Physicochemical and Engineering Aspects, 1997. 123-124: p. 329-337.

18. Predoi, D., et al., Iron oxide in a silica matrix prepared by the sol-gel method. Thin Solid Films, 2007. 515(16): p. 6319-6323.

19. Xu, Y., et al., Controllable Gelation of Methylcellulose by a Salt Mixture. Langmuir, 2004. 20(15): p. 6134-6138.

20. Otsuka, T., T. Maeda, and A. Hotta, Effects of Salt Concentrations of the Aqueous Peptide-Amphiphile Solutions on the Sol-Gel Transitions, the Gelation Speed, and the Gel Characteristics. The Journal of Physical Chemistry B, 2014. 118(39): p. 11537-11545.

21. Qin, J. and S. Gu, A Method Of Extracting Silica At First And Then Extracting Alumina From Fly Ash. 2008, PINGSHUO IND LTD: WO.

22. Jinguo, Q.I.N. and G.U. Songqing, Process For Recovery Of Silica Followed By Alumina From Coal Fly Ash. 2011, PINGSHUO IND LTD: US. 
APPENDICES 


\section{Theoretical Maximum Concentration of Complete TMOS Hydrolysis}

$$
\begin{aligned}
& \mathrm{MW}_{\text {TMOS }}=152.22 \mathrm{~g} / \mathrm{mol} \\
& \mathrm{MW}_{\text {water }}=18.015 \mathrm{~g} / \mathrm{mol} \\
& \rho_{\text {TMOS }}=1.03 \mathrm{~g} / \mathrm{mL} \\
& \rho_{\text {water }}=0.997 \mathrm{~g} / \mathrm{mL} \\
& 1 \mathrm{~mL} \mathrm{TMOS} \cdot \frac{1.03 \mathrm{~g} \mathrm{TMOS}}{1 \mathrm{~mL} \mathrm{TMOS}} \cdot \frac{1 \mathrm{~mol} \mathrm{TMOS}}{152.22 \mathrm{~g} \mathrm{TMOS}} \cdot \frac{4 \mathrm{~mol} \mathrm{Water}}{1 \mathrm{~mol} \mathrm{TMOS}} \cdot \frac{18.015 \mathrm{~g} \text { Water }}{1 \mathrm{~mol} \mathrm{Water}} \\
& \cdot \frac{1 \mathrm{~mL} \text { Water }}{0.997 \mathrm{~g} \text { Water }}=0.489 \mathrm{~mL} \text { Water }
\end{aligned}
$$

Total Volume $=1 \mathrm{~mL}$ TMOS $+0.489 \mathrm{~mL}$ Water $=1.489 \mathrm{~mL}$

$$
\text { Max Concentration }=\frac{1 \mathrm{~mL} \mathrm{TMOS}}{1.489 \mathrm{~mL}} \cdot 100 \%=\mathbf{6 7 . 2} \%
$$

\section{Example for Adjustment of $\mathrm{pH}$ in Sodium Silicate Sol-Gel Processing}

$$
\begin{aligned}
& \mathrm{MW}_{\mathrm{Na}_{2} \mathrm{O}}=61.98 \mathrm{~g} / \mathrm{mol} \\
& \mathrm{MW}_{\mathrm{HCl}}=36.46 \mathrm{~g} / \mathrm{mol} \\
& \frac{\mathrm{Na}_{2} \mathrm{O}}{\mathrm{Na}_{2} \mathrm{SiO}_{3}}=10.6 \% \\
& \rho_{\mathrm{Na}_{2} \mathrm{SiO}_{3}}(\mathrm{in} \mathrm{solution})=1.39 \mathrm{~g} / \mathrm{mL} \\
& \rho_{\mathrm{HCl}}=1.2 \mathrm{~g} / \mathrm{mL} \\
& 0.5 \mathrm{~mL} \mathrm{Na}_{2} \mathrm{SiO}_{3} \cdot \frac{1.39 \mathrm{~g} \mathrm{Na}_{2} \mathrm{SiO}_{3}}{1 \mathrm{~mL} \mathrm{Na}_{2} \mathrm{SiO}_{3}} \cdot \frac{0.106 \mathrm{~g} \mathrm{Na}_{2} \mathrm{O}}{1 \mathrm{~g} \mathrm{Na}_{2} \mathrm{SiO}_{3}} \cdot \frac{1 \mathrm{~mol} \mathrm{Na}_{2} \mathrm{O}}{61.98 \mathrm{~g} \mathrm{Na}_{2} \mathrm{O}} \cdot \frac{2 \mathrm{~mol} \mathrm{NaOH}}{1 \mathrm{~mol} \mathrm{Na}_{2} \mathrm{O}} \\
& \quad=0.002377 \mathrm{~mol} \mathrm{NaOH}^{2}
\end{aligned}
$$

Targeting $\mathrm{pH}=9 . \mathrm{pOH}=14-9=5$

$10^{-5}=0.00001 \mathrm{~mol} \mathrm{NaOH}$

Total $\mathrm{NaOH}$ to Neutralize

$0.002377-0.00001=0.002367 \mathrm{~mol} \mathrm{NaOH}$ 
$0.002367 \mathrm{~mol} \mathrm{HCl} \cdot \frac{36.46 \mathrm{~g} \mathrm{HCl}}{1 \mathrm{~mol} \mathrm{HCl}} \cdot \frac{1 \mathrm{~mL} \mathrm{HCl}}{1.2 \mathrm{~g} \mathrm{HCl}} \cdot \frac{1 \mathrm{~mL} \mathrm{Soln} \mathrm{HCl}}{0.37 \mathrm{~mL} \mathrm{HCl}}=\mathbf{0 . 1 9 4} \mathbf{~ m L ~ N a O H}$

\section{Example Volume Reduction of Glass}

Reduction in glass size is proportional to the concentration of the Silane used for encapsulation and solids content of the wastewater. If salt hydration occurs, then volume reduction is lessened because water is retained. Further, volume reduction is proportional to density of the glass which will vary across samples. A conservatively small Silicon Dioxide density is used for the following calculation.

Total Solids of Wastewater $=1 \%$

Concentration of TMOS $=40 \%$

$\rho_{\mathrm{TMOS}}=1.03 \mathrm{~g} / \mathrm{mL}$

$\rho_{\mathrm{SiO}_{4}}=2.65 \mathrm{~g} / \mathrm{mL}$

$\mathrm{MW}_{\mathrm{TMOS}}=152 \mathrm{~g} / \mathrm{mol}$

$\mathrm{MW}_{\mathrm{SiO}_{4}}=124 \mathrm{~g} / \mathrm{mol}$

Starting Volume $=1 \mathrm{~mL}$ TMOS Solution $+1 \mathrm{~mL}$ Wastewater $=2 \mathrm{~mL}$

Ending Volume $=$ Volume of $\mathrm{SiO}_{4}+1 \mathrm{~mL}$ Wastewater $\cdot$ Total Solids Content

$1 \mathrm{~mL}$ TMOS Solution $\cdot \frac{0.4 \mathrm{~mL} \mathrm{TMOS}}{1 \mathrm{~mL} \text { TMOS Solution }} \cdot \frac{1.03 \mathrm{~g} \mathrm{TMOS}}{1 \mathrm{~mL} \mathrm{TMOS}} \cdot \frac{124 \mathrm{~g} \mathrm{SiO}_{4}}{152 \mathrm{~g} \mathrm{TMOS}}$

$$
\cdot \frac{1 \mathrm{~mL} \mathrm{SiO}_{4}}{2.65 \mathrm{~g} \mathrm{SiO}_{4}}=0.127 \mathrm{~mL} \mathrm{SiO}_{4}
$$

Ending Volume $=0.127 \mathrm{~mL} \mathrm{SiO}_{4}+1 \mathrm{~mL} \cdot 0.01=0.137 \mathrm{~mL}$

Volume Reduction $=\frac{\text { Starting Volume }- \text { Ending Volume }}{\text { Starting Volume }} \cdot 100 \%=\mathbf{9 3 . 7} \%$ 
VITA

Alex William Kearns

402 River Ridge Drive

Sanders, KY 41083

Alex.Kearns574@gmail.com

EDUCATION

University of Louisville, J.B. Speed School of Engineering

M. Eng. in Chemical Engineering

2018-2019

University of Louisville, J.B. Speed School of Engineering

B.S. in Chemical Engineering

2014-2018

\section{EMPLOYMENT}

Louisville Gas \& Electric and Kentucky Utilities

Graduate Intern, Technology Research and Analysis

2018-2019

Ashland Inc.

Process Engineering Co-op, Calvert City, KY

2016-2017

University of Louisville

Residential Advisor and Undergraduate Teaching Assistant

2015

\section{TECHNICAL CERTIFICATIONS}

OSHA 10-Hour

Received

2018

First AID CPR AED

2018

Two-Phase Flow Pressure Relief Device Sizing

2017

HONORS AND AWARDS

Robert Neiman Memorial Scholar

Received

Henry Vogt Scholar

2018

Gatton Academy Scholar

2014

2014 